\title{
Proteome studies in Legume (Phaseolus vulgaris L.)
}

\author{
Alireza Taleei* \\ Professor in the Department of Agronomy \& Plant breeding, Iran
}

Submission: February 11, 2018; Published: March 14, 2018

*Corresponding author: Alireza Taleei, Professor in the Department of Agronomy \& Plant breeding, Faculty of Agricultural Sciences and Engineering, College of Agriculture and Natural Resources, University of Tehran, Karaj, P.0. Box 31587-71787, Iran, Email: ataleei@ut.ac.ir

\begin{abstract}
Proteomics techniques were used to identify the underlying mechanism of the early stage of symbiosis between the common bean (Phaseolus vulgaris $L$.) and bacteria. Proteins from roots of common beans inoculated with bacteria were separated using two-dimensional polyacrylamide gel electrophoresis and identified using mass spectrometry. From 483 protein spots, 29 plant and 3 bacterial proteins involved in the early stage of symbiosis were identified. Of the 29 plant proteins, the expression of 19 was up regulated and the expression of 10 was down regulated. Up regulated proteins included those involved in protein destination/storage, energy production, and protein synthesis; whereas the down regulated proteins included those involved in metabolism. Many up regulated proteins involved in protein destination/storage were chaperonins and proteasome subunits. These results suggest that defense mechanisms associated with induction of chaperonins and protein degradation regulated by proteasomes occur during the early stage of symbiosis between the common bean and bacteria.
\end{abstract}

Keywords: Phaseolus vulgaris, Symbiosis, Proteomics, Rhizobium etli, Root

\section{Introduction}

Legumes can establish intracellular interactions with symbiotic as well as pathogenic microbes. Such intracellular accommodation of bacteria always leads to the formation of a membrane compartment, the interface between the cytoplasm of the host and the bacterial cell [1-12]. In exchange for plant photosynthates, the endosymbiotic rhizobia convert nitrogen to ammonia which is supplied to the plant for incorporation into amino acids and ultimately proteins. In root endosymbiotic, bacteria-derived lipochito oligosaccharides with an $\mathrm{N}$-acetyl glucosamine backbone, the Nod factors, play a key role in mediating recognition [4]. The perception of Nod factors through LysM domain receptor kinases [13-16] induces a chain response in host roots that includes ion flux changes [17], membrane depolarization [16], calcium spiking [11], cytoskeleton modifications [18], activation of cortical cell division [14], and root hair curling. During the early stage of Nod factor recognition, swelling of the root hair tip occurs, and is followed by new tip outgrowth, root hair branching [2], nodule primordium initiation, and formation of curled root hairs [9]. The bump-shaped nodule primordia become visible on the root surface 3 days after inoculation [15]. Nodulins, plant proteins expressed during infection and nodule maturation, play important roles in cell signaling, differentiation, and cycle reactivation [13]. Global analytical procedures applied to the study of symbiosis in leguminous plants have elucidated the roles of some symbiosis related proteins, including amylases [16], membrane trans-porters [10], glycolytic enzymes [19], malate dehydrogenase, phosphoenol pyruvate carboxylase [3], and chaperonins [12]. Although many studies of symbiosis have been carried out to date, most of these have focused on model legumes. The common bean is one of the most ancient of food crops [6]; but, no genomic sequence data is yet available for this important plant. As with other legumes, beans can enter a nitrogen-fixing endosymbiotic with prokaryotes of the genus Rhizobium, allowing them to grow and produce protein-rich seeds even on nitrogen poor soil. Common beans thus play a crucial role in the introduction of fixed nitrogen into both agricultural and natural systems. During the early stage of symbiotic interaction between bean plants and bacteria, root hair deformation occurs [1], and this is the first visual evidence of symbiosis [7], but the molecular mechanisms underlying the symbiotic response in legumes, such as the perception of Nod factors and next signal transduction and nodule organogenesis, stay unknown, especially in the common bean.

In this study proteins from roots of common beans inoculated with bacteria were separated using two-dimensional polyacrylamide gel electrophoresis and identified using mass spectrometry. From 483 protein spots, 29 plant and 3 bacterial proteins involved in the early stage of symbiosis were identified. Out of the 29 plant proteins, the expression of 19 was up regulated and the expression of 10 was down regulated. Up regulated proteins included those involved in protein destination/storage, energy production, and protein synthesis; whereas the down regulated proteins included those involved in metabolism. Many 
up regulated proteins involved in protein destination/storage were chaperonins and proteasome subunits. These results suggest that defense mechanisms associated with induction of chaperonins and protein degradation regulated by proteasomes occur during the early stage of symbiosis between the common bean and bacteria.

\section{References}

1. Cárdenas L, Vidali L, Dominguez J, Pérez H, Sánchez F, et al. (1998) Rearrangement of actin microfilaments in plant root Hairs responding to Rhizobium etli nodulation signals. Plant Physiol 116(3): 871-877.

2. Catoira R, Galera C, de Billy F, Penmetsa RV, Journet EP, et al. (2000) Four genes of Medicago truncatula controlling components of a Nod factor transduction pathway. Plant Cell 12: 1647-1665.

3. Delgado-Alvarado A, Walker RP, Leegood RC, et al. (2007) Phosphoenolpyruvate carboxykinase in developing pea seeds is associated with tissues involved in solute transport and is nitrogenresponsive. Plant Cell Environ 30: 225-235.

4. D'Haeze W, Holsters M (2002) Nod factor structures, responses, and perception during initiation of nodule development. Glycobiology 12 : 79R-105R.

5. El Yahyaoui F, Küster H, Ben Amor B, Hohnjec N, Pühler A, et al Expression profiling in Medicago truncatula identifies more than 750 genes differentially expressed during nodulation, including many potential regulators of the symbiotic program. Plant Physiol 2004,136: 3159-3176.

6. Gepts P (1998) Origin and evolution of common bean: past events and recent trends. Hortic Sci 33: 1124-1130.

7. Isoi T, Yoshida S (1991) Deficient nitrogen fixation of common-bean (Phaseolus vulgaris). Soil Sci Plant Nutr 37: 559-563.

8. Ivanov S, Fedorova E, Bisseling T (2010) Intracellular plant microbe associations: secretory pathways and the formation of perimicrobial compartments. Curr Opin Plant Biol 13(4): 372-377.
9. Madsen LH, Tirichine L, Jurkiewicz A, Sullivan JT, Heckmann Ab, et al. (2000) The molecular network governing nodule organogenesis and infection in the model legume. Lotus japonicas Nat Commun 1: 1-12.

10. Matzke M, Weiger TM, Papp I, Matzke AJ (2009) Nuclear membrane ion channels mediate root nodule development. Trends Plant Sci 14: 295-298.

11. McAinsh MR, Pittman JK (2009) Shaping the calcium signature. New Phytol 181: 275-294.

12. Morris AC, Djordjevic MA (2001) Proteome analysis of cultivar-specific interactions between Rhizobium leguminosarum biovar trifolii and subterranean clover cultivar Woogenellup. Electrophoresis 22: 586598.

13. Oldroyd GE, Downie JA (2008) Coordinating nodule morphogenesis with rhizobial infection in legumes. Annu Rev Plant Biol 59: 519-546.

14. Oldroyd GED, Downie JA (2006) Nuclear calcium changes at the core of symbiosis signaling. Curr Opin Plant Biol 9: 351-357.

15. Penmetsa RV, Cook DR (1997) legume ethylene-insensitive mutant hyperinfected by its rhizobial symbiont. Science 275: 527-530.

16. Radutoiu S, Madsen LH, Madsen EB, Felle HH, Umehara Y, et al. (2003) Plant recognition of symbiotic bacteria requires two LysM receptor like kinases. Nature 425: 585-592.

17. Shaw SL, Long SR (2003) Nod factor elicits two separable calcium responses in Medicago truncatula root hair cells. Plant Physiol 131: 976-984.

18. Takemoto D, Hardham AR (2004) The cytoskeleton as a regulator and target of biotic interactions in plants. Plant Physiol 136: 3864-3876.

19. White J, Prell J, James EK, Poole P (2007) Nutrient sharing between symbionts.Plant Physiol 144: 604-614.

Your next submission with Juniper Publishers
will reach you the below assets
- Quality Editorial service
- Swift Peer Review
- Reprints availability
- E-prints Service
- Manuscript Podcast for convenient understanding
- Global attainment for your research
- Manuscript accessibility in different formats
( Pdf, E-pub, Full Text, Audio)
- Unceasing customer service
Track the below URL for one-step submission
https://juniperpublishers.com/online-submission.php

